\title{
SOX9 Gene Mutation
}

National Cancer Institute

\section{Source}

National Cancer Institute. SOX9 Gene Mutation. NCI Thesaurus. Code C153512.

A change in the nucleotide sequence of the SOX9 gene. 